\title{
Elemental composition of otoliths used to trace estuarine habitats of juvenile gag Mycteroperca microlepis along the west coast of Florida
}

\author{
Peter J. Hanson ${ }^{1, *}$, Christopher C. Koenig ${ }^{2}$, Vincent S. Zdanowicz ${ }^{3}$ \\ ${ }^{1}$ National Oceanic and Atmospheric Administration, Center for Coastal Fisheries and Habitat Research, Beaufort, \\ North Carolina 28516, USA \\ ${ }^{2}$ Institute for Fishery Resource Ecology, Department of Biological Science, Florida State University, Tallahassee, Florida 32306, USA \\ ${ }^{3}$ National Oceanic and Atmospheric Administration, Northeast Fisheries Science Center, James J. Howard Marine Sciences \\ Laboratory, Highlands, New Jersey 07732, USA
}

\begin{abstract}
The spatial relationships and relative contributions of known juvenile gag Mycteroperca microlepis habitats to specific fishery grounds and populations along the Florida west coast are virtually unknown. To determine if otolith composition is a valid tracer of specific nursery sites and can be used to classify adult fish to their nursery area, chemical concentrations in juvenile gag otoliths ( $\mathrm{Li}, \mathrm{Na}, \mathrm{K}, \mathrm{Mg}, \mathrm{Ca}, \mathrm{Sr}, \mathrm{Ba}, \mathrm{Mn}, \mathrm{Cu}, \mathrm{Pb}, \delta^{13} \mathrm{C}$ and $\delta^{18} \mathrm{O}$ ) were measured for 4 nursery areas along the Florida west coast in 1992, 1995 and 1996. Classification of fish to nursery area was by parametric discriminant function analysis and neural network simulation; both gave similar results in the spatial and temporal patterns of classification error and in identification of important classification variables (Mn, Sr and $\delta^{13} \mathrm{C}$ ). Classification success rates ranged from 66 to $100 \%$. Interannual variability in otolith composition had a negative effect on classification success rate at the spatial scale of site separation $(<200 \mathrm{~km})$. At regional spatial scales $(>300 \mathrm{~km})$ the year effect was reduced and classification success remained high without consideration of year class. Analysis of classification errors supports the separation of sites into northern and southern groups. The observed negative trend in otolith $\mathrm{Sr}$ and positive trend in otolith Mn with increasing latitude are positively correlated with corresponding trends in groundwater $\mathrm{Sr}$ and sediment $\mathrm{Mn}$, respectively, which are hypothesized to be the proximal causes for the otolith trends. Otolith composition is a valid technique for classifying juvenile gag to estuarine habitats along the west coast of Florida. Classification error rates of less than $10 \%$ are obtained when the year class of the fish is considered. Similar error rates were achieved across multi-year data at regional spatial scales.
\end{abstract}

KEY WORDS: Otolith chemistry $\cdot$ Juvenile habitat $\cdot$ Gag $\cdot$ Manganese $\cdot$ Strontium $\cdot$ Carbon isotopes Resale or republication not permitted without written consent of the publisher

\section{INTRODUCTION}

Gag Mycteroperca microlepis is an important fishery species in the eastern Gulf of Mexico that is approaching an overfished state (Schirripa \& Legault 1997, Turner et al. 2001). Advanced signs of fishing pressure are apparent at the population level, as indicated by declines since the 1970s in adult biomass, size, age, and proportion of males in the population (Coleman et al. 1996, Koenig et al. 1996). There appears to be a strong link between offshore adult biomass in the fishery and estuarine juvenile biomass of the same year class that was on nursery grounds 2 to $3 \mathrm{yr}$ earlier (Koenig \& Coleman 1998, Fitzhugh et al. 2001, C. Koenig \& F. Coleman unpubl. data). This observation, combined with the relative facility of estimating juvenile biomass on grassbeds (Koenig \& Coleman 1998), offers the possibility for recruitment forecasting through development of a recruitment index based on juvenile abundance. This approach requires knowl- 
edge of the spatial distribution of juvenile grassbeds and their relative importance as recruitment sources to the fishery.

West Florida seagrass beds probably vary in importance as source habitats for fishery production. Beds have been lost or degraded (Durako et al. 1987, Zieman \& Zieman 1989), and others may not provide the location, protection and/or food resources necessary for juvenile growth and survival. Knowledge of highquality juvenile-source habitats would flag those seagrass areas most important for management, such as those suitable for the creation of marine protected areas, and would reveal which areas are most appropriate for the assessment of annual juvenile abundance for use in recruitment forecasting. Recruitment forecasting offers an alternative or adjunct to the current practice of hindcasting fishery stocks, and would allow enactment of proactive management strategies in anticipation of a weak juvenile recruitment year (de Lafontaine et al. 1992). The ability to trace the juvenile habitats of adult fishes through the elemental chemistry of their otoliths would provide a potentially useful tool in future refinements of management of gag stocks.

Otoliths provide a unique combination of chronological and locational characteristics (Campana \& Thorrold 2001) that are attractive in the investigation of the age structure and migratory history of fish populations. Otoliths, continuously accreting carbonate structures of the inner ear, may provide the means of identifying fishes from different juvenile-source grounds by virtue of associations between the elemental chemistries of the otoliths and resident habitats (see e.g. recent review by Campana 1999 and papers by Limburg 1995, Thorrold et al. 1998a,b, Hanson \& Zdanowicz 1999, Bath et al. 2000, Gillanders \& Kingsford 2000, Kimura et al. 2000 and Secor et al. 2001). Otolith formation is isolated from direct contact with the habitat, and otolith composition is highly regulated compared to other biogenic calcified structures (Campana \& Thorrold 2001). Not all elements present in the habitat (in water, food or sediment) and potentially available to fishes are present in measurable concentrations in otoliths compared to other tissues (Hanson \& Zdanowicz 1999). The list of elements useful for linking otolith and habitat chemistries generally includes $\mathrm{Sr}$, $\mathrm{Ba}, \mathrm{Mn}, \mathrm{C}$ and $\mathrm{O}$ isotopes, Fe and $\mathrm{Pb}$ (Campana 1999). Use of otolith chemistry to track fish habitats does not require knowledge of physiological mechanisms or environmental sources, which often are not well known. However, the extent to which they are understood places the technique on firmer ground.

In this investigation, we undertook the elemental analysis of juvenile gag otoliths collected over $3 \mathrm{yr}$ along the west coast of Florida at 4 principal estuarine nursery locations. We sought to establish the geographic variability of chemical signals in otoliths as a means for classification of the fish to particular nursery grounds. Further, we investigated the temporal variability of these signals to establish the need to restrict spatial differentiation within a single year class, or the possibility for a temporally stable signal that can be applied across year classes. We interpreted the observed patterns of spatial and temporal variability in otolith composition in relation to chemical and physical patterns in the environment, and evaluated them as causal factors for otolith composition.

\section{MATERIALS AND METHODS}

Otolith samples. Juvenile gag were collected by trawl from shallow grassbeds (depth range 1 to $2 \mathrm{~m}$ ) at four locations along the Florida west coast in $3 \mathrm{yr}$ (Fig. 1, Table 1). Standard length (SL) ranged from 68 to $234 \mathrm{~mm}$. Fish were sampled at varying times during the 3 annual nursery periods, ranging from early June to late October. Upon capture, the fish were placed on ice and returned to the laboratory, where SL and whole weights were recorded. Sagittal otolith pairs were removed, washed with water to remove adhering tissue, dried, weighed and stored at room temperature. One otolith of each pair was used for elemental analysis, the other for stable isotope analysis. Otolith weight ranged from 2.22 to $30.58 \mathrm{mg}$.

Elemental analysis. All reagents used were ultrapure grade and all implements and containers were

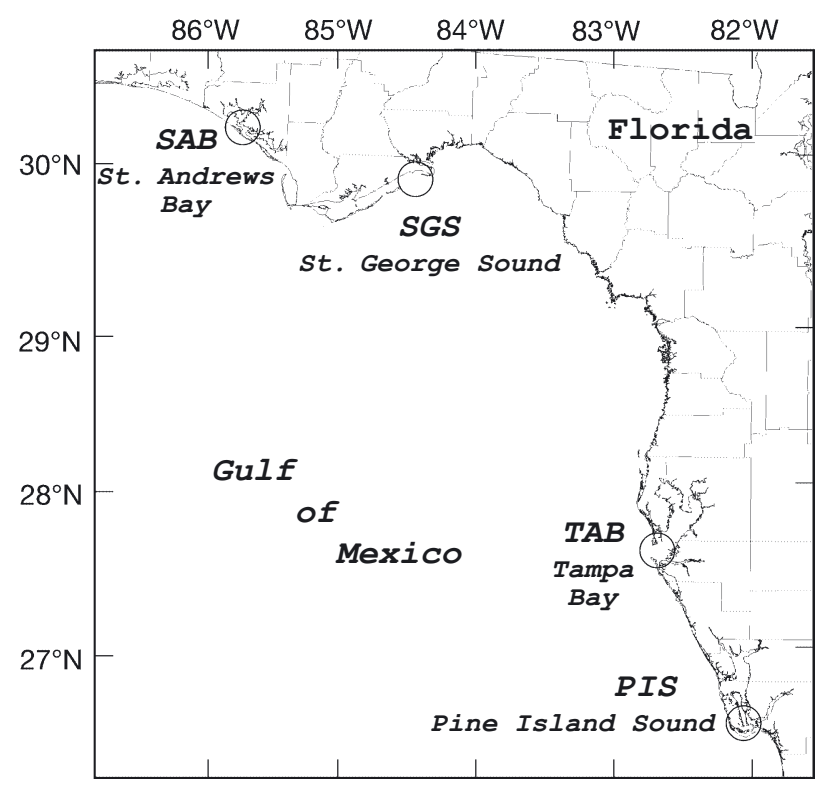

Fig. 1. Mycteroperca microlepis. Nursery sites along west coast of Florida sampled for juvenile gag 
Table 1. Mycteroperca microlepis. Juvenile gag sample locations, dates and fish sizes. Capture dates given as mo/d; $\mathrm{n}$ : sample size; SL: standard length, mean (SD) min./max.; WW: whole wet wt, mean (SD) min./max.

\begin{tabular}{|c|c|c|c|c|c|c|}
\hline \multirow{2}{*}{$\begin{array}{l}\text { Site } \\
\text { PIS (Pine Island Sound) }\end{array}$} & \multicolumn{2}{|c|}{ Capture dates } & \multirow{2}{*}{$\begin{array}{l}\text { Location centroid } \\
26.50^{\circ} \mathrm{N}, 82.13^{\circ} \mathrm{W}\end{array}$} & \multirow{2}{*}{$\frac{\mathrm{n}}{20}$} & \multirow{2}{*}{$\begin{array}{c}\text { SL }(\mathrm{mm}) \\
155.6 \\
(23.0) \\
123 / 193\end{array}$} & \multirow{2}{*}{$\begin{array}{c}\text { WW }(\mathrm{g}) \\
101.1 \\
(44.1) \\
42.4 / 177.8\end{array}$} \\
\hline & 1992: & $\begin{array}{l}7 / 28-30 \\
8 / 1,8 / 3 \\
9 / 16,9 / 25,9 / 27\end{array}$ & & & & \\
\hline & 1995: & $6 / 7$ & $26.50^{\circ} \mathrm{N}, 82.13^{\circ} \mathrm{W}$ & 9 & $\begin{array}{c}93.2 \\
(17.5) \\
68 / 117\end{array}$ & $\begin{array}{c}21.0 \\
(10.5) \\
7.3 / 36.4\end{array}$ \\
\hline & 1996: & $9 / 30,10 / 22$ & $26.50^{\circ} \mathrm{N}, 82.13^{\circ} \mathrm{W}$ & 10 & $\begin{array}{c}174.0 \\
(28.2) \\
145 / 234\end{array}$ & $\begin{array}{c}134.0 \\
(74.0) \\
72.4 / 307.5\end{array}$ \\
\hline TAB (Tampa Bay) & 1996: & $7 / 31$ & $27.62^{\circ} \mathrm{N}, 82.72^{\circ} \mathrm{W}$ & 10 & $\begin{array}{c}151.0 \\
(10.8) \\
138 / 167\end{array}$ & $\begin{array}{c}83.1 \\
(21.6) \\
62.1 / 122.9\end{array}$ \\
\hline \multirow[t]{3}{*}{ SGS (St. George Sound) } & 1992: & $9 / 1,9 / 4$ & $29.91^{\circ} \mathrm{N}, 84.49^{\circ} \mathrm{W}$ & 10 & $\begin{array}{c}181.7 \\
(4.6) \\
176 / 187\end{array}$ & $\begin{array}{c}162.4 \\
(16.9) \\
138.5 / 187.9\end{array}$ \\
\hline & 1995: & $\begin{array}{l}7 / 7-8,7 / 11 \\
7 / 22,9 / 8\end{array}$ & $29.91^{\circ} \mathrm{N}, 84.49^{\circ} \mathrm{W}$ & 10 & $\begin{array}{c}134.0 \\
(20.7) \\
114 / 177\end{array}$ & $\begin{array}{c}71.6 \\
(41.2) \\
37.8 / 175.0\end{array}$ \\
\hline & 1996: & $9 / 19,9 / 30$ & $29.91^{\circ} \mathrm{N}, 84.49^{\circ} \mathrm{W}$ & 10 & $\begin{array}{c}191.8 \\
(12.7) \\
175 / 216\end{array}$ & $\begin{array}{c}182.7 \\
(31.2) \\
137.6 / 228.1\end{array}$ \\
\hline SAB (St. Andrews Bay) & 1995: & $\begin{array}{l}7 / 31,8 / 14-15 \\
8 / 23,8 / 29,9 / 19\end{array}$ & $30.14^{\circ} \mathrm{N}, 85.72^{\circ} \mathrm{W}$ & 10 & $\begin{array}{c}177.6 \\
(18.5) \\
157 / 207\end{array}$ & $\begin{array}{c}132.8 \\
(41.1) \\
91.8 / 212.6\end{array}$ \\
\hline
\end{tabular}

cleaned with dilute nitric acid $\left(\mathrm{HNO}_{3}\right)$ and rinsed with 18 megaohm, double-deionized water $\left(\mathrm{DDIH}_{2} \mathrm{O}\right)$. Before analysis, otoliths were carefully decontaminated using the following procedure. First, they were soaked in $\mathrm{DDIH}_{2} \mathrm{O}$ to hydrate any remaining biological residue adhering to the surface of the sample; this residue was removed using fine-tipped forceps. Next, the otoliths were soaked in $3 \%$ hydrogen peroxide for 5 min to dissolve any remaining biological residue. They were then immersed for $5 \mathrm{~min}$ in $1 \% \mathrm{HNO}_{3}$ to remove surface contamination, and then flooded with $\mathrm{DDIH}_{2} \mathrm{O}$ for $5 \mathrm{~min}$ to remove the acid. Finally, they were dried under a Class 100 laminar-flow hood and stored in plastic vials. In preparation for instrumental analysis, each otolith was weighed to the nearest $0.01 \mathrm{mg}$, placed in a plastic centrifuge tube and dissolved in $1 \% \mathrm{HNO}_{3}$. Internal standards were added to all solutions to compensate for possible instrument drift.

Elemental concentrations were measured either by quadrupole inductively-coupled plasma mass spectrometry (QICPMS) (Perkin-Elmer ELAN 5000) or by atomic absorption spectrophotometry (AAS) (PerkinElmer Model 3300). Levels of Li, Mg, Ba, Mn, Cu and $\mathrm{Pb}$ were determined by QICPMS using matrixmatched external calibration standards; levels of Ca and $\mathrm{Sr}$ were quantified by QICPMS using external standards without matrix matching. Concentrations of $\mathrm{Na}$ and $\mathrm{K}$ were measured by AAS. Samples were analyzed in random order to avoid possible sequence effects. Procedural blanks and a standard reference material (SRM) were concurrently digested and analyzed following the same procedures. The SRM was NIST 915a (Calcium Carbonate Clinical Standard) obtained from the National Institute of Standards and Technology (Gaithersburg, Maryland), and was used to estimate the recovery, precision and accuracy of the method. This SRM is not certified for trace metal content, so only non-certified values are available for a few elements. Relevant values are $\left(\mu \mathrm{g} \mathrm{g}^{-1}\right.$ dry weight; $\mathrm{Ca}$ as \% dry weight): $\mathrm{Mg}, 1.0 ; \mathrm{Ca}, 40.0 ; \mathrm{Mn}, 0.6 ; \mathrm{Cu}$, 0.95. Our results (mean $\pm \mathrm{SD}, \mathrm{n}=9$ ) were: $\mathrm{Mg}, 1.05 \pm$ $0.08 ; \mathrm{Ca}, 39.9 \pm 1.0 ; \mathrm{Mn}, 0.61 \pm 0.02 ; \mathrm{Cu}, 0.97 \pm 0.04$. Using this method, samples of an otolith 'certified reference material' (CRM) (Yoshinaga et al. 2000), produced at the National Institute of Environmental Studies (NIES) of Japan, have been analyzed on several occasions, although not concurrently with these samples. Certified values for the CRM are ( $\mu \mathrm{g} \mathrm{g}^{-1}$ dry weight; Ca as \% dry weight): Na, $2230 \pm 100 ; \mathrm{K}, 282 \pm$ 8; Mg, $21 \pm 1 ; \mathrm{Ca}, 38.8 \pm 0.5 ; \mathrm{Sr}, 2360 \pm 50 ; \mathrm{Ba}, 2.89 \pm$ 0.09 . Our results were (mean $\pm \mathrm{SD}, \mathrm{n}=18$ ): $\mathrm{Na}, 2380 \pm$ $103 ; \mathrm{K}, 334 \pm 21 ; \mathrm{Mg}, 21.1 \pm 2.5 ; \mathrm{Ca}, 37.6 \pm 1.8 ; \mathrm{Sr}$ $2240 \pm 124 ; \mathrm{Ba}, 2.84 \pm 0.53$. Lithium $\left(0.198 \pm 0.042 \mu \mathrm{g} \mathrm{g}^{-1}\right)$ 
was also measured, but its concentration is not certified in the CRM. However, in a blind intercomparison, 10 pairs of otoliths were randomly split and analyzed at 2 laboratories using different methods. We analyzed one set using the method described above, while the other set was analyzed at a collaborating laboratory using high-resolution inductively coupled plasma massspectrometry and isotope dilution. Results of the Li analyses were indistinguishable.

Isotope analysis. Otoliths were rinsed with $\mathrm{DDIH}_{2} \mathrm{O}$ to remove any residual tissue, dried in the laminar-flow hood, weighed to $0.01 \mathrm{mg}$, and stored in plastic vials. Carbon and oxygen isotope ratios were determined by mass spectrometry (VG Isogas, Sira II) coupled to an automated sample-processing device (Micromass UK, Multiprep). Since optimum sample size for analysis was 300 to $400 \mu \mathrm{g}$ and otolith weight range was 2.22 to $30.58 \mathrm{mg}$, otoliths were powdered (stainless steel ball mill) for analysis. Isotope ratio results are expressed relative to Pee Dee belemnite (PDB) with an external precision (SD) of $0.05 \%$ for $\delta^{13} \mathrm{C}$ and $0.08 \%$ for $\delta^{18} \mathrm{O}$, based on replicate analyses of a laboratory carbonate standard calibrated to NIST standards.

Data analysis. The objective was to optimize the classification of juvenile fish to nursery sites based on relative otolith concentrations of chemical constituents. Classification proceeded with several combinations of the data to explore spatial (site) and temporal (year) relationships affecting classification error estimates. Classification was conducted using both parametric discriminant-function analysis (DFA) and artificial neural network simulations (ANNS). DFA has been widely applied in otolith classification (Campana et al. 1994, 1995, Gillanders \& Kingsford 1996, Dufour et al. 1998, Thorrold et al. 1998a), whereas ANNS is a relative newcomer (Thorrold et al. 1998b). The use of both approaches provided independent assessments of classification bias since, in contrast to parametric DFA, ANNS operated in a supervised learning mode (as used herein) makes no assumptions about underlying data models or distributions (e.g. Geman et al. 1992, Goh 1995). Two methods were judged to be an advantage for accurate resolution of the relative influence of multiple chemical variables on the spatial and temporal variation of otolith composition and on resultant classification success in a system of unknown structure and complexity.

The underlying assumption of functional normality for parametric analyses was investigated with the Shapiro-Wilks test for normality (SAS Institute 1990). Of 96 possible cases (12 variables by 8 site-years), 67 were accepted as random samples from a normal distribution $(p \geq 0.05)$, and overall departure from normality was considered small. Many parametric analyses were repeated with log-transformed data based on the positive skewness observed in most non-normal cases. Log-transformation had no effect on statistical conclusions.

The dependence of chemical composition on fish length was investigated by analysis of covariance (ANCOVA)(SAS Institute 1989b). Correlation between variables, both for the data reported here and archived data from other sources, was determined by Pearson correlation coefficients (SAS Institute 1990) and linear regression (SAS Institute 1989b).

Classification by DFA (SAS Institute 1989a) used a pooled covariance matrix, which resulted in a linear discriminant function, to reduce the potential for detecting misclassifications. The optimum model for classification was approached by the sequential addition of chemical variables in the order of decreasing univariate $r$-square until a minimum error-count estimate was reached. Cross-validation was used for error estimation to reduce bias, whereby, with a training sample size $n$, the discriminant functions are determined $\mathrm{n}$ times, each time with a different set of $n-1$ observations. The heldout observation was classified after each determination and the overall error is based on the aggregate error of the $\mathrm{n}$ cases. Error-count estimates (ECE) are the proportion of misclassified observations by group. Overall error-rate estimates (ERE) and overall posterior probability error-rate estimates (PPERE), which tend to have lower variances than ECE, were used to assess errors. Overall ERE are based on the weighted average of the group-specific error estimates, where prior probabilities are the weights. PPERE are smoothed error estimates used to reduce variance compared to ERE.

ANNS was conducted with an enhanced, feedforward, back-propagation algorithm (BackpropMomentum: learning parameter, $\eta=0.1$; momentum term, $\mu=0.5$ ) (SNNS Group 1998) using varying network topographies. Networks are trained by an iterative series (number of cycles) of feed-forward weight computations and feed-backward weight adjustments (back-propagation) to achieve minimum error. Mean square error (MSE), the squared difference between computed and training outputs summed over all output neurons and observations, and divided by the number of observations, was used to gauge network performance during training. The probability of correct classification (PCC), the proportion of test observations correctly classified, was used to measure classification performance. The early stopping method for training and cross-validation for testing (Haykin 1999) were used to optimize network learning and network ability to correctly map new data, i.e. to generalize. The data records were randomly partitioned into training $(90 \%)$ and testing $(10 \%)$ sets to implement early stopping; the training set was further randomly portioned into estimation and validation sets (Haykin 1999). 
The ability of a network to generalize depends on the complexity of the existing problem, the size of the data set available for training, the representativeness of the data to the problem, and the structure of the network (Haykin 1999). Here, only network structure can be manipulated to affect generalization. Given the number of input (ni) and output (no) nodes, chemical variables and sites or regions, respectively, which are $a$ priori determined by the classification problem, only the number of hidden nodes $(n h)$ can be varied to optimize structure. With ni and no set, the optimum network was determined experimentally by a series of simulations with $n h$ increasing from zero until optimum nh was reached. Using a heuristic developed here, optimum $n h$ was determined as the minimum $n h$ where MSE was near a minimum or approached a practical asymptote, where PCC was at or near a maximum, where stability (error around MSE during network training) of the learning curve (MSE vs number of training cycles) was relatively high, and where the initial slope of the early learning curve was steep and was followed by an asymptotic approach to zero. The average ability and associated error of a network to classify the fish were determined by a series of 10 simulations, an ensemble, in which training and test sets were repartitioned for each simulation.

The relative importance of individual chemical and fish-size input variables to the performance of neural networks was determined by partition of synaptic weights after the method of Garson (1991). The partition parameters for the input variables were ensembleaveraged and the averages compared using the RyanEinot-Gabriel-Welsch multiple range test $(\alpha=0.05)$ (SAS Institute 1989b) to compare their relative importance.

Haykin (1999) pointed out that when the number of training patterns is less than 30 times the number of free parameters (which is always the case here) the chance for overfitting and a reduction in generalization is pos- sible. The ability of networks to generalize was tested by reducing the number of free parameters, using the results of the multiple range tests to reduce inputs to the 3 most important variables. The optimum number of hidden nodes was determined as before. The ability of the larger networks $(n i=12)$ to generalize was tested by comparing their error rates (PCC) with smaller networks $(n i=3)$ based on the same data $(n=89)$.

\section{RESULTS}

Otolith concentrations of the 12 chemical constituents showed varying geographical patterns and levels of variance among the 4 sites and 3 yr (Table 2). A significant covariate effect of fish SL was detected for 6 ( $\mathrm{Li}, \mathrm{Na}, \mathrm{Mg}, \mathrm{Mn}, \mathrm{Sr}$ and $\mathrm{Ba})$ of the 12 chemical variables, whereas only $\mathrm{Na}$ and $\mathrm{Mg}$ had homogeneous slopes (ANCOVA, $\mathrm{p} \leq 0.05$ ). For all 48 possible regressions ( 6 variables $\times 8$ site-years) only 13 were significant ( $\mathrm{p} \leq 0.05)$, but all significant slopes were negative, indicating a weak trend of decreasing otolith concentration with growth for these elements. Classification by DFA and ANNS was conducted with both covariate unadjusted and adjusted data, whereby, under the assumption of homogeneity of slopes for the 6 variables with significant covariate effects, otolith concentrations were adjusted to the overall mean SL using the common pooled slope. The results for both DFA and ANNS were unchanged (Tables 3 \& 4), although the importance of $\mathrm{Mg}$ increased for both analyses after adjustment (Tables 3 \& 5). All further analyses reported are from covariate unadjusted data.

The success rates for multi-year DFA classification to site ranged from $66 \%$ for all sites $(n=89)$ to $94 \%$ for the 2 sites with 3 yr of data each (PIS and SGS, $\mathrm{n}=69$ ) (Table 3). The year-effect is evident in the comparison of the 3 by-year analyses (1992, 1995 and 1996) where, although the error estimates were similar, the number

Table 2. Mycteroperca microlepis. Concentration data for elements and stable isotopes in juvenile gag otoliths. Means (SD) shown

\begin{tabular}{|c|c|c|c|c|c|c|c|c|}
\hline \multirow{2}{*}{$\begin{array}{l}\text { Element/ } \\
\text { isotope }\end{array}$} & \multicolumn{3}{|c|}{ Pine Island Sound } & \multirow{2}{*}{$\begin{array}{c}\text { Tampa Bay } \\
1996\end{array}$} & \multicolumn{3}{|c|}{ St. George Sound } & \multirow{2}{*}{$\begin{array}{l}\text { St. Andrews } \\
\text { Bay } 1995\end{array}$} \\
\hline & 1992 & 1995 & 1996 & & 1992 & 1995 & 1996 & \\
\hline $\operatorname{Li}\left(\mu g g^{-1}\right)$ & $0.225(0.043)$ & $0.294(0.142)$ & $0.229(0.052)$ & $0.276(0.048)$ & $0.225(0.054)$ & $0.258(0.086)$ & $0.222(0.030)$ & $0.213(0.041)$ \\
\hline $\mathrm{Na}\left(\mathrm{mg} \mathrm{g}^{-1}\right)$ & $2.97(0.27)$ & $3.47(0.23)$ & $3.14(0.24)$ & $3.20(0.26)$ & $3.06(0.24)$ & $3.35(0.32)$ & $3.07(0.20)$ & $3.16(0.31)$ \\
\hline $\mathrm{K}\left(\mu \mathrm{g} \mathrm{g}^{-1}\right)$ & $440(60)$ & $473(28)$ & $448(38)$ & $448(57)$ & $375(40)$ & $325(28)$ & $483(17)$ & $448(23)$ \\
\hline $\operatorname{Mg}\left(\mu g g^{-1}\right)$ & $29.8(4.0)$ & $35.5(4.1)$ & $29.9(4.6)$ & $32.9(1.8)$ & $32.6(2.1)$ & $37.4(4.8)$ & $30.0(3.5)$ & $29.7(3.4)$ \\
\hline Сa $(\%)$ & $38.7(0.93)$ & $40.6(5.7)$ & $39.4(1.1)$ & $38.6(0.75)$ & $38.4(2.0)$ & $38.8(1.1)$ & $39.2(0.78)$ & $38.7(1.6)$ \\
\hline $\operatorname{Sr}\left(\mathrm{mg} \mathrm{g}^{-1}\right)$ & $1.63(0.15)$ & $1.78(0.33)$ & $1.87(0.13)$ & $1.62(0.12)$ & $1.43(0.10)$ & $1.39(0.09)$ & $1.63(0.10)$ & $1.36(0.07)$ \\
\hline $\mathrm{Ba}\left(\mu \mathrm{g} \mathrm{g}^{-1}\right)$ & $6.33(6.10)$ & $4.51(2.37)$ & $4.16(2.29)$ & $3.88(2.20)$ & $3.46(0.53)$ & $1.68(0.54)$ & $3.38(0.750)$ & $2.33(0.76)$ \\
\hline $\operatorname{Mn}\left(\mu g^{-1}\right)$ & $0.622(0.212)$ & $1.68(0.59)$ & $1.04(0.42)$ & $0.911(0.453)$ & $2.14(0.62)$ & $2.20(1.39)$ & $2.76(0.57)$ & $1.39(0.51)$ \\
\hline $\mathrm{Cu}\left(\mu \mathrm{g} \mathrm{g}^{-1}\right)$ & $1.08(0.31)$ & $0.966(0.411)$ & $0.898(0.278)$ & $1.06(0.46)$ & $1.06(0.41)$ & $1.04(0.33)$ & $0.865(0.278)$ & $0.756(0.160)$ \\
\hline $\mathrm{Pb}\left(\mu \mathrm{g} \mathrm{g}^{-1}\right)$ & $0.216(0.194)$ & $0.102(0.102)$ & $0.132(0.080)$ & $0.165(0.176)$ & $0.371(0.306)$ & $0.0983(0.0618)$ & $0.111(0.073)$ & $0.147(0.071)$ \\
\hline$\delta^{13} \mathrm{C}(\%)$ & $-5.41(0.76)$ & $-4.75(0.76)$ & $-3.46(0.53)$ & $-4.28(1.13)$ & $-2.92(0.84)$ & $-5.24(0.77)$ & $-2.61(0.37)$ & $-3.87(0.58)$ \\
\hline$\delta^{18} \mathrm{O}(\%)$ & $-2.04(0.89)$ & $-3.18(1.30)$ & $-1.26(0.41)$ & $-1.23(0.54)$ & $-1.79(0.60)$ & -1.93 (1.19) & $-1.54(0.78)$ & $-2.06(0.18)$ \\
\hline
\end{tabular}


Table 3. Mycteroperca microlepis. Discriminant function analyses (DFA) of otolith chemical data for classification of fish to nursery area. PIS: Pine Island Sound; TAB: Tampa Bay; SGS: St. George Sound; SAB: St. Andrews Bay

\begin{tabular}{|c|c|c|c|c|c|c|}
\hline $\mathrm{n}$ & Year & Class & $\begin{array}{l}\text { Class } \\
\text { levels }\end{array}$ & $\begin{array}{l}\text { Variables at } \\
\text { min. ECE }\end{array}$ & $\begin{array}{l}\text { Overall } \\
\text { ERE }\end{array}$ & $\begin{array}{c}\text { Overall } \\
\text { 1-PPERE }\end{array}$ \\
\hline 89 & All & Site (PIS, TAB, SGS, SAB) & 4 & $\mathrm{Mn}, \mathrm{Sr}, \delta^{13} \mathrm{C}, \mathrm{K}^{\mathrm{a}}$ & 0.28 & 0.66 \\
\hline 69 & All & Site (PIS, SGS) & 2 & $\mathrm{Mn}, \mathrm{Sr}, \delta^{13} \mathrm{C}$ & 0.02 & 0.94 \\
\hline 30 & 1992 & Site (PIS, SGS) & 2 & $\mathrm{Mn}$ & 0 & 0.97 \\
\hline 29 & 1995 & Site (PIS, SGS, SAB) & 3 & $\mathrm{~K}, \mathrm{Sr}$ & 0.07 & 0.92 \\
\hline 30 & 1996 & Site (PIS, TAB, SGS) & 3 & $\mathrm{Mn}, \mathrm{Sr}, \delta^{13} \mathrm{C}, \mathrm{Li}$ & 0.10 & 0.92 \\
\hline 89 & All & Region $^{\mathrm{b}}$ & 2 & $\mathrm{Mn}, \mathrm{Sr}, \delta^{13} \mathrm{C}$ & 0.02 & 0.94 \\
\hline 89 & All & Site $^{\mathrm{c}}$ (PIS, TAB, SGS, SAB) & 4 & $\mathrm{Mn}, \mathrm{Mg}, \mathrm{Sr}, \delta^{13} \mathrm{C}$ & 0.28 & 0.69 \\
\hline
\end{tabular}

and combination of chemical variables differed significantly. $\mathrm{Mn}, \mathrm{Sr}$ and $\delta^{13} \mathrm{C}$ were generally the more important variables, the exception being 1995, where $\mathrm{K}$ was important and Mn was not included. Analysis of error patterns observed in the misclassification of fish to site suggested that fish were segregated into 2 regions based on otolith composition, a northern region composed of SAB and SGS sites and a southern region composed of PIS and TAB sites. With all data ( $n=89$ ), classification to region was $94 \%$ successful, while classification to site was $66 \%$ successful.

Success rates for multi-year ANNS classification to site using all 12 chemical variables $(n i=12)$ ranged from $76 \%$ for all sites $(\mathrm{n}=89)$ to $92 \%$ for PIS and SGS sites $(\mathrm{n}=69)$ (Table 4). The single-year classification success rates ranged from 80 to $100 \%$. As in the DFA analysis, fish appear to be segregated into 2 regions. The success rate for classification to region was $95 \%$.
Simulations with a reduced number of free parameters ( $n i=3$; smaller networks) yielded virtually the same results as with all input variables ( $n i=12$; larger networks) (Table 4). This indicates that both network sizes are equally capable of generalization in modeling the chemical composition of otoliths for classification to site and region.

The results of the synaptic weight-partitioning (ANNS) and multiple-range tests (Table 5), which agree with those of DFA (Table 3), show $\mathrm{Mn}$ and $\mathrm{Sr}$ to be the more important chemical variables. The overall order is $\mathrm{Mn}=\mathrm{Sr}>\delta^{13} \mathrm{C} \geq \mathrm{K}$, with the remaining 8 variables of decreasing and variable importance. A temporal effect on variable importance is evident in the by-year analyses, where in $1995 \mathrm{~K}$ was most important but was not important in other years; Mn was of little influence in 1995, but was important in all other years.

Table 4. Mycteroperca microlepis. Artificial neural network simulations (ANNS) of otolith chemical data for classification of fish to nursery area. Average results for 10-network ensembles. Site abbreviations as in Table 3

\begin{tabular}{|c|c|c|c|c|c|c|c|c|}
\hline $\mathrm{n}$ & Year & Class & $\begin{array}{l}\text { Class } \\
\text { levels }\end{array}$ & $\begin{array}{r}\text { Optim } \\
\text { network st } \\
n i \times n h\end{array}$ & $\begin{array}{l}\text { mum } \\
\text { structure } \\
h \times n o\end{array}$ & $\begin{array}{l}\text { Training } \\
\text { cycles }\end{array}$ & MSE (SD) & $\mathrm{PCC}(\mathrm{SD})$ \\
\hline 89 & All & Site (PIS, TAB, SGS, SAB) & 4 & $12^{\mathrm{a}} 6$ & 4 & $75-450^{b}$ & $0.151(0.061)$ & $0.762(0.162)$ \\
\hline 69 & All & Site (PIS, SGS) & 2 & 121 & 2 & $80-250$ & $0.0182(0.0096)$ & $0.917(0.088)$ \\
\hline 30 & 1992 & Site (PIS, SGS) & 2 & 121 & 2 & $100-150$ & $0.00592(0.00275)$ & 1.00 \\
\hline 29 & 1995 & Site (PIS, SGS, SAB) & 3 & 124 & 43 & $50-175$ & $0.0451(0.0262)$ & $0.800(0.172)$ \\
\hline 30 & 1996 & Site (PIS, TAB, SGS) & 3 & 124 & 43 & $75-300$ & $0.0359(0.0438)$ & $0.800(0.172)$ \\
\hline 89 & All & Region & 2 & 121 & 2 & $80-300$ & $0.0184(0.0102)$ & $0.950(0.064)$ \\
\hline 89 & All & Site (PIS, TAB, SGS, SAB) & 4 & 31 & 4 & 200 & $0.367(0.011)$ & $0.725(0.053)$ \\
\hline 89 & All & Region $^{\mathrm{c}}$ & 2 & 31 & 2 & $50-250$ & $0.0342(0.0125)$ & $0.950(0.064)$ \\
\hline 89 & All & Site (PIS, TAB, SGS, SAB) & 4 & 134 & 4 & $60-450$ & $0.178(0.100)$ & $0.762(0.124)$ \\
\hline
\end{tabular}


Table 5. Mycteroperca microlepis. Partition of neural network-connection weights and multiple-range tests on ensembleaveraged weight fractions. Ensemble-averaged $(\mathrm{n}=10)$ weight fractions for chemical and SL variables listed in descending order for large-network simulations in Table 4. Means with same letter are not significantly different $(\alpha=0.05)$

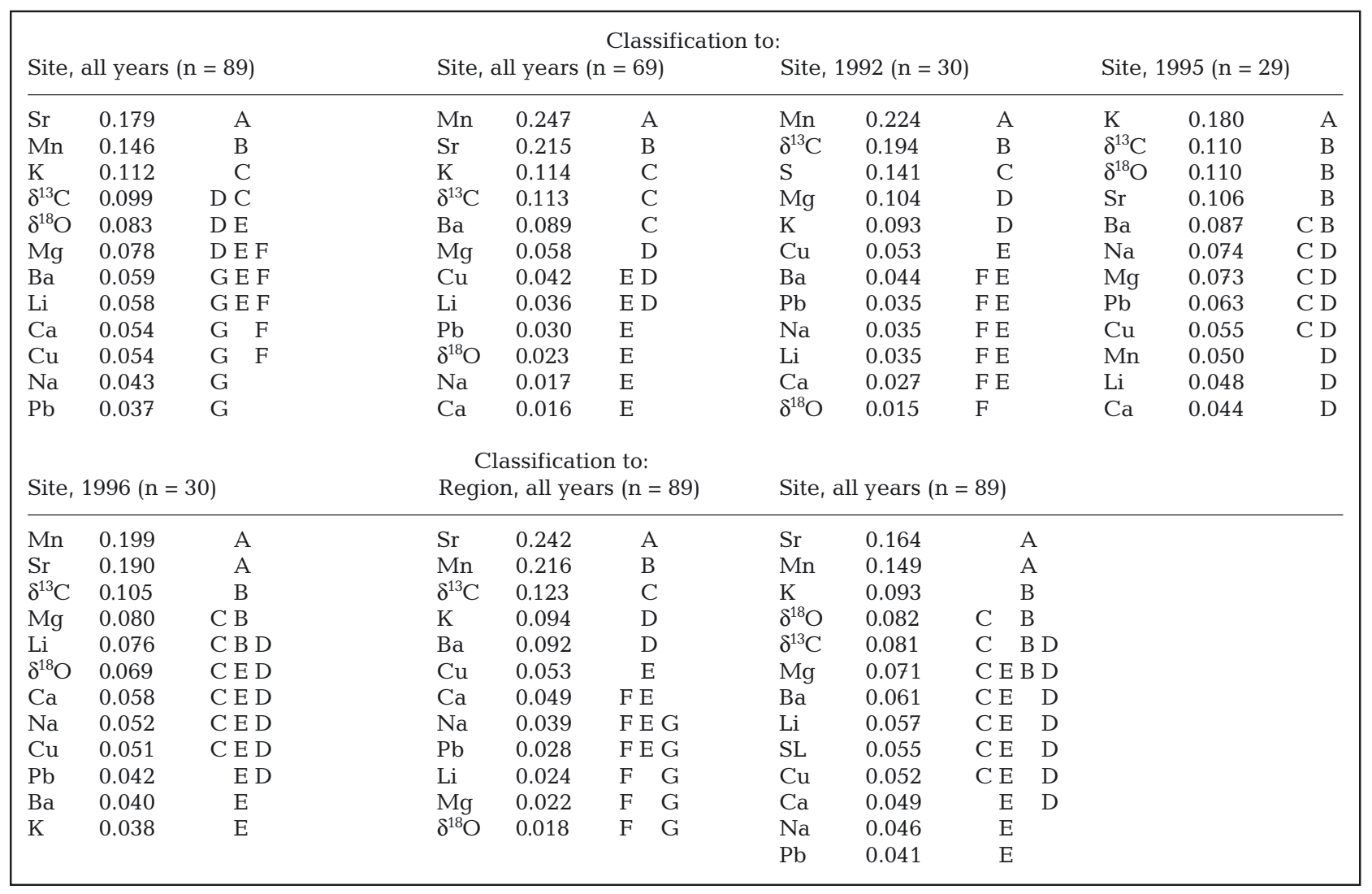

\section{DISCUSSION}

Since there is no reason to expect a covariate SL effect on otolith elemental concentrations to be other than species-related, the explanation for the large number of nonsignificant regressions of concentration on SL apparently lies in the narrow range in SL observed at many sites (Table 1). Covariate adjustment had no effect on classification success by DFA and ANNS. The covariate effect observed for 6 of 12 variables, although significant, is apparently weak compared to the effect of spatial and temporal differences in otolith concentrations.

Comparison of DFA and ANNS results shows the 2 techniques provide similar classification success rates. Analyses across all sites and years combined yielded lower success rates for both techniques $(66 \%$ for DFA and 76 and $72 \%$ for ANNS, small and large networks, respectively) compared to analyses across all sites by individual years (92 to $97 \%$ for DFA and 80 to $100 \%$ for ANNS). This is consistent with an interannual variation in environmental levels that forces otolith composition - a temporal effect. In contrast are DFA and ANNS results for PIS and SGS sites across all years, where success rates were high, 94 and $92 \%$, respectively. Temporal effects were not as important across the larger spatial scale of separation of PIS and SGS along the west Florida coast. Analysis of the spatial distribution of misclassifications of fish to site provides an explanation for these seemingly disparate results. The same pattern existed for both DFA (Fig. 2) and ANNS (Fig. 3) for classification to site across all years. The majority of classification errors occurred between SGS and SAB in the north (27 and $42 \%$ ) and between PIS and TAB in the south ( 63 and $42 \%$ ). Only 10 and $17 \%$ of errors occurred between these northern and southern groups. This supports the supposition that a discontinuity in environmental chemistry exists in the area separating these regional groups that is of sufficient magnitude and duration to have affected otolith composition in a similar manner for the 3 sampled years. This supposition is further strengthened by the results for direct classification to region by both DFA and ANNS, where the ECE between regional groups was 0.02 and 0.05 , respectively, compared to 0.03 and 0.04 , respectively, when regional classification was resolved from classifications made to site. 


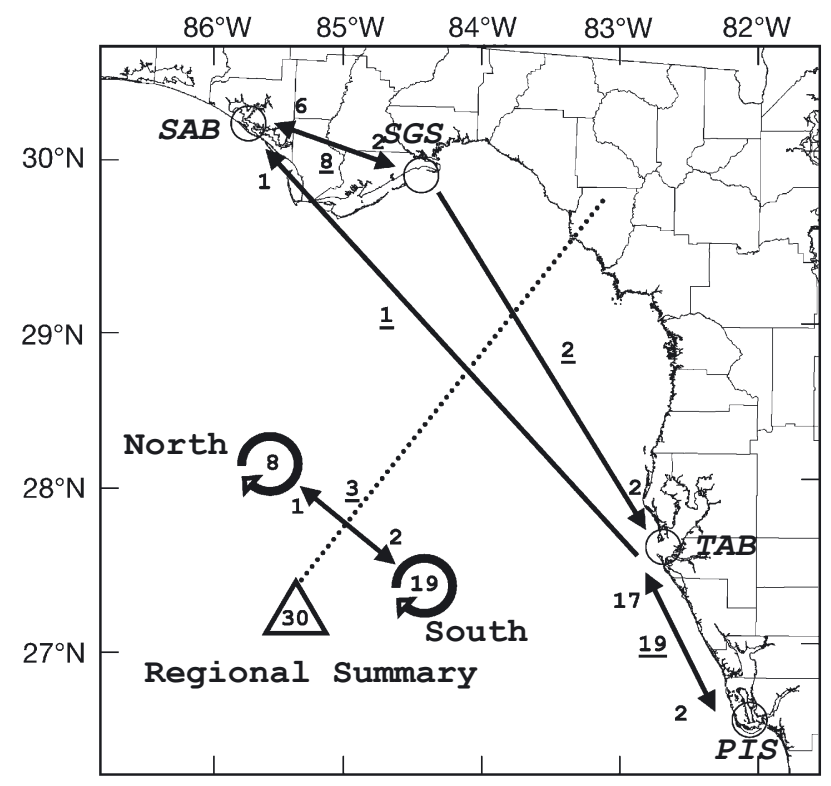

Fig. 2. Mycteroperca microlepis. Spatial distribution of errors in discriminant function analysis for classifications of fish ( $\mathrm{n}=$ 89) to site across all years based on otolith composition. Error presented as error count estimate (ECE) in \%. Continuous arrows indicate direction and ECE between sites or regions; underlined numbers indicate total ECE between sites or regions; dotted line indicates separation of regional groups. For regional summary, number in triangle is total ECE among all sites; numbers in circular arrows indicate total ECE among sites within regional groups. Site abbreviations as in Fig. 1

DFA and ANNS results indicate that $\mathrm{Mn}, \mathrm{Sr}, \delta^{13} \mathrm{C}$, and $\mathrm{K}$ are the most important variables for classification. The only unexpected result was that of $\mathrm{K}$, which is, as are $\mathrm{Na}$ and $\mathrm{Ca}$, actively regulated by fishes and not expected to respond in plasma and otolith levels to variations in water composition. The influence of $\mathrm{K}$ on the classification results was largely dependent on 2 uncharacteristically low means (SGS 1995 and 1992) derived from unresolved causes. Mean K concentrations for the other 6 site-years were similar, and in the lower part of the concentration range measured in otoliths of several marine fish species $\left(571 \pm 5 \mathrm{\mu g} \mathrm{g}^{-1}\right.$; mean $\mathrm{K} \pm \mathrm{SE}, \mathrm{n}=13$ ) (summarized by Campana 1999). It is likely that $\mathrm{K}$ will be of limited general value for fish classification. For these reasons, K was excluded from the smaller network simulations in which the 3 other most important input variables were used.

The virtually identical results of the larger and smaller ANNS networks confirm the representativeness of the data for the complexity level of the classification problem and support the conclusion that ANNS was reliably able to model the data with the existing sample size. Further, the validity of the importance ranking of input variables by weight-partitioning is supported by the observation that the 3 highestranked chemical variables ( $\mathrm{K}$ excluded for reasons discussed in preceeding paragraph) provided the same result for classification to site and to region as when all chemical variables were used.

$\mathrm{Mn}, \mathrm{Sr}$ and $\delta^{13} \mathrm{C}$ were the principal variables influencing classification using both DFA and ANNS, and they displayed distinct concentration patterns in otolith composition along the coast. Sr concentrations were generally higher at the lower-latitude sites (PIS and $T A B)$. The Mn pattern was opposite, with larger values at higher-latitude sites (SGS and SAB). Delta ${ }^{13} \mathrm{C}$ values showed a weak positive trend with increasing latitude that was consistent with the inverse relationship between $\delta^{13} \mathrm{C}$ and temperature discussed below.

The principal source of inorganic elements commonly found in otoliths is water by uptake across the gill or intestine followed by physiological controls dependent on the element. For marine fishes, intestinal assimilation is important because of the continual oral intake of water required for osmoregulation. Assimilation from food is probable (Limburg 1995, Buckel et al. 2004), but not well-characterized (Campana 1999). In the absence of simultaneously sampled water data (and food data in the case of $\delta^{13} \mathrm{C}$ ), an environmental explanation for the observed along-coast gradients in otolith composition must depend on archived data.

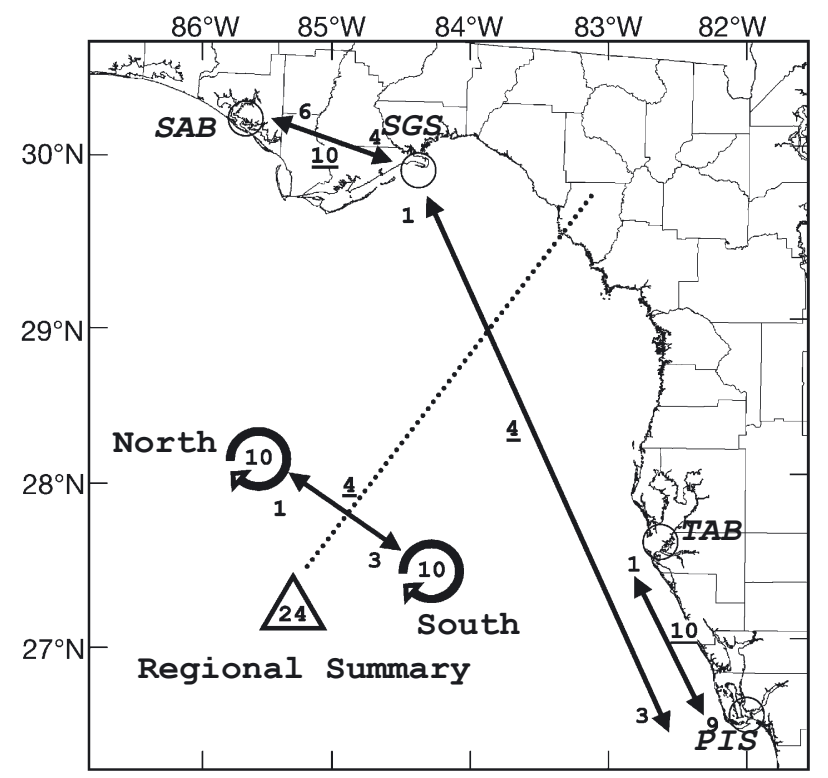

Fig. 3. Mycteroperca microlepis. Spatial distribution of errors in artificial neural network simulation for classification of fish ( $n=89$ ) to site across all years based on otolith composition. Error presented as error count estimate (ECE) in \%. Symbols as in Fig. 2, site abbreviations as in Fig. 1 


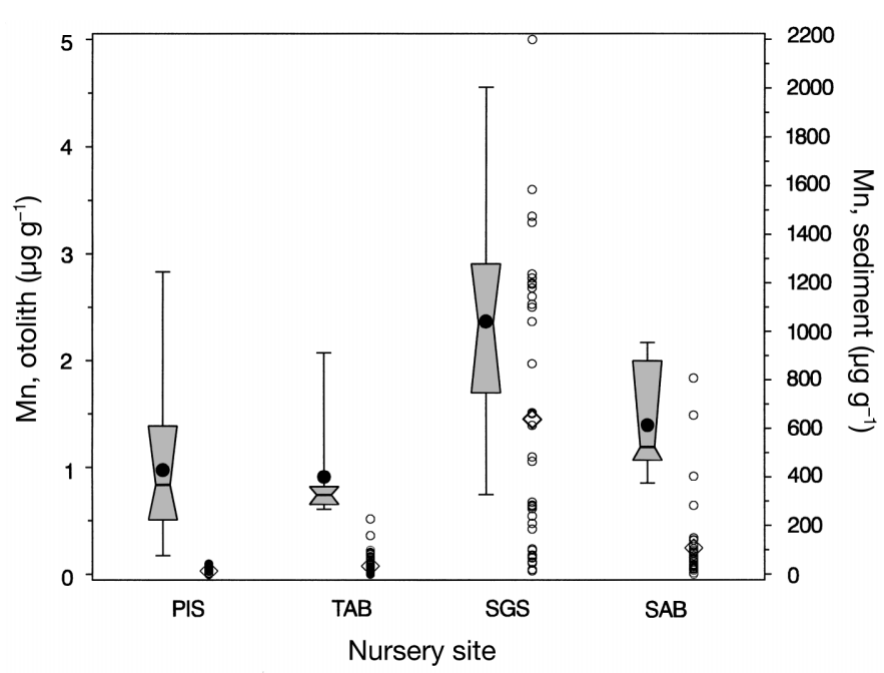

Fig. 4. Mycteroperca microlepis. Manganese concentrations in gag otoliths and bottom sediments as a function of nursery site. Otolith data from present study presented as box plots, where horizontal line at notch = median, data point $=$ mean, height of box = interquartile range and whiskers = data range. Sediment data are total Mn (dry wt) presented as sample concentrations $(\circ)$ and means $(\diamond)$ from 3 sources over period 1984-1991: NOAA National Benthic Surveillance Project, 1984-1989, $\mathrm{n}=33$ (Hanson et al. 1993); NOAA National Mussel Watch Project, 1986-1990, n = 85 (Daskalakis \& O'Connor 1995); State of Florida, 1984-1991, n = 164 (Seal et al. 1994). Site abbreviations as in Fig. 1

\section{Manganese}

Whereas a coherent data set for dissolved $\mathrm{Mn}$ is unknown for the sampled area, sediment data exists for many estuarine and coastal locations. Manganese behavior is dominated by its redox cycle of remobilization from the solid phase under anoxic conditions and release into pore water of the sediment surface layer. Oxic conditions encountered near the sediment surface can rapidly recycle $\mathrm{Mn}$ back to the solid phase. Most $\mathrm{Mn}$ is retained in the microbially mediated redox cycle (Thamdrup et al. 1994). However, a net benthic efflux of Mn is expected to support increased concentrations of dissolved phase $\mathrm{Mn}$ in the water column above Mn-rich sediments. A significant Mn pathway from sediment to water has been demonstrated (Warnken et al. 2001).

Release of sediment $\mathrm{Mn}$ into the overlying water would increase its availability for incorporation into otoliths. To test this hypothesis, sediment Mn data for estuarine and coastal locations between PIS and SAB (Hanson et al. 1993, Seal et al. 1994, Daskalakis \& O'Connor 1995) were plotted against otolith Mn (Fig. 4). The correlation between mean Mn in otoliths and sediments by site was 0.98 (Pearson correlation coefficient, $\mathrm{p}=0.0198$ ). This points to sediments as an important source of $\mathrm{Mn}$ in otoliths and to the regional gradient in sediment $\mathrm{Mn}$ as the probable cause of the observed regional gradient in otolith Mn. Elevated sediment Mn levels at the northern sites (SGS and $\mathrm{SAB}$ ) represent sediments naturally enriched in $\mathrm{Mn}$ that support elevated dissolved and otolith Mn levels compared to the southern sites (PIS and TAB).

\section{Strontium}

Fish residence along salinity gradients or at different salinities is known to induce otolith $\mathrm{Sr}$ concentrations proportional to dissolved concentrations of the element (Bath et al. 2000). Dissolved Sr concentration in estuarine systems generally has a positive, conservative relationship with salinity in response to mixing of riverine and marine waters along the estuarine mixing axis (Ingram \& Sloan 1992). Since juvenile gag are sedentary and prefer polyhaline waters (20 to 30 PSU in the upper estuarine-coastal range: Koenig \& Coleman 1998), their otolith composition would not be expected to be influenced by large variation in salinity at different nursery sites or by residence along salinity gradients caused by mixing of typical river and ocean waters. Salinity (PSU) measured during sampling and expressed (by site) over all years supports this expectation (mean, median, minimum, maximum): PIS = 29.3, $30,14,36 ; \mathrm{TAB}=31.5,31,24,36 ; \mathrm{SGS}=30.2,30,26,36$; $\mathrm{SAB}=28.2,29,22,33$.

Possible causes for the observed along-coast trends in otolith $\mathrm{Sr}$ include habitat temperature and discharge of Sr-rich groundwater to coastal rivers, estuaries and shelf waters. Temperature can account for only 2 to $7 \%$ of the observed decrease in otolith $\mathrm{Sr}$ with latitude. These estimates are based on a $\mathrm{Sr}$-temperature relationship for juvenile spot (Leiostomus xanthurus) (Bath et al. 2000) and monthly mean sea-surface temperatures computed from satellite data (Vazquez et al. 1998) (Table 6) for each shallow site (depth $\leq 2 \mathrm{~m}$ ) over the typical 7 mo nursery period (April through October).

Discharge of groundwater into coastal waters of the southeastern United States, including both coasts of Florida, is a relatively common phenomenon and a significant source, relative to seawater concentrations, of dissolved constituents, such as $\mathrm{Sr}, \mathrm{Ba}, \mathrm{Ra}$, and nutrient nitrogen and phosphorus (Fanning et al. 1982, 1987, Cable et al. 1996, Moore \& Shaw 1998, Shaw et al. 1998, Rutkowski et al. 1999, Swarzenski et al. 2001). In the absence of dissolved Sr data for the nursery sites, variation in $\mathrm{Sr}$ concentration in Florida groundwater (Hansard \& Silvanima 1999) and springs (Rosenau et al. 1977) that discharge into shelf waters provides evi- 
Table 6. Computed 7 mo (April to October) mean sea-surface temperatures $\left(\mathrm{SST}^{\circ}{ }^{\circ} \mathrm{C}\right.$ ) by site. Site mean computed for a $5 \times 5$ square-cell grid centered at each site from monthly average SST data by cell from Vazquez et al. (1998). Cells are $5 \mathrm{~km}$ on each side

\begin{tabular}{|lcccc|}
\hline Site & 1992 & 1995 & 1996 & All years \\
\hline Pine Island Sound (PIS) & 27.5 & 28.8 & 28.4 & 28.2 \\
Tampa Bay (TAB) & 27.0 & 28.4 & 27.9 & 27.8 \\
St. George Sound (SGS) & 26.2 & 27.2 & 26.8 & 26.7 \\
St. Andrews Bay (SAB) & 25.5 & 27.1 & 26.9 & 26.5 \\
All sites & 26.5 & 27.9 & 27.5 & - \\
\hline
\end{tabular}

dence to support groundwater discharge as the source of the observed along-coast trends in otolith Sr. Congruence of otolith and groundwater trends are demonstrated by the 0.94 correlation (Pearson correlation coefficient, $\mathrm{p}=0.0601$ ) between mean otolith $\mathrm{Sr}$ and groundwater $\mathrm{Sr}$ measured in proximity to nursery sites (Fig. 5). Salinity-indexed mixing curves for dissolved $\mathrm{Sr}$ and $\mathrm{Ca}$ were computed using mean values in Florida groundwater, world average river water (Martin \& Whitfield 1981) and average seawater (Martin \& Whitfield 1981, Drever 1988) as mixing end-members to estimate $\mathrm{Sr}: \mathrm{Ca}_{\text {water }}$ ratios expected at each nursery site at 30 PSU, which was the overall median salinity

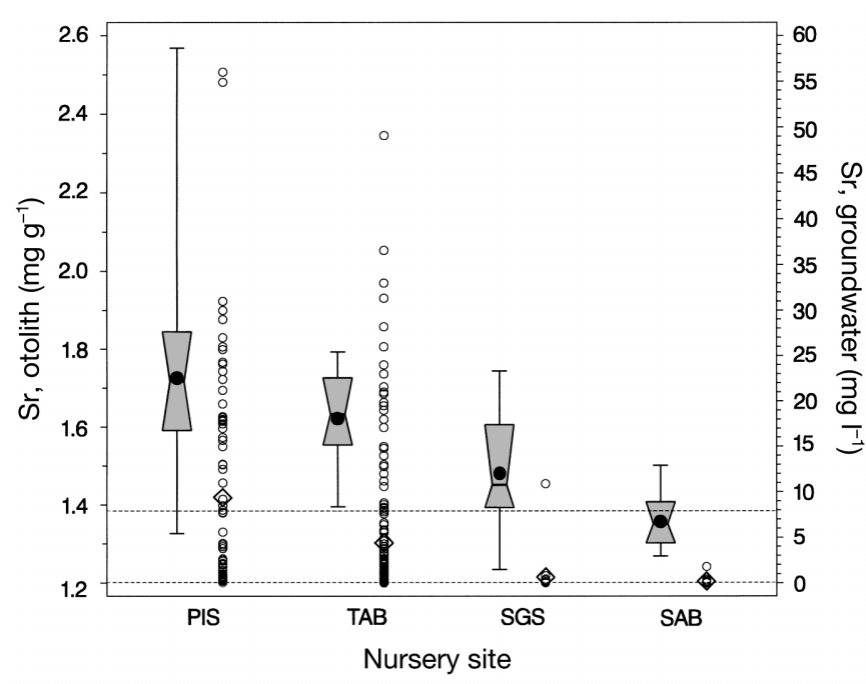

Fig. 5. Mycteroperca microlepis. Strontium concentrations in gag otoliths and groundwater (wells and springs) as a function of nursery site. Otolith data from present study are presented as box plots as detailed in Fig. 4 legend. Groundwater data are sample concentrations $(\circ)$ and means $(\diamond)$ for groundwater wells $(\mathrm{n}=616)$ over period 1991 to 1997 (Hansard \& Silvanima 1999) and springs $(n=82)$ over period 1968 to 1975 (Rosenau et al. 1977). Typical strontium concentrations in seawater $\left(7.9 \mathrm{mg} \mathrm{l}^{-1}\right.$ ) (Palmer \& Edmond 1989) and in river water $\left(0.06 \mathrm{mg} \mathrm{l}^{-1}\right.$ ) (Martin \& Whitfield 1981) are shown (dashed lines). Site abbreviations as in Fig. 1 measured during sampling (Table 7). From these $\mathrm{Sr}: \mathrm{Ca}_{\text {water }}$ ratios and experimental partition coefficients (Bath et al. 2000), estimates of otolith $\mathrm{Sr}: \mathrm{Ca}_{\text {otolith }}$ ratios were computed for each site. Measured and estimated values of Sr:Ca $\mathrm{Ca}_{\text {otolith }}$ are in good agreement (Table 7), even noting that the partition coefficient was derived with a different species (juvenile spot Leiostomus xanthurus) at higher $\mathrm{Sr}: \mathrm{Ca}_{\mathrm{water}}$ ratios (12.5 to $22.8 \mathrm{mmol}$ $\mathrm{mol}^{-1}$ ) than estimated here, and at $25^{\circ} \mathrm{C}$ which is about 1 to $3^{\circ} \mathrm{C}$ lower than at the nursery sites (Table 6). The Crescent Beach data confirms the discharge of lowsalinity water from the Floridan aquifer system (the same discharge source for the gag nursery sites) into near-coastal seawater at $\mathrm{Sr}$ concentrations $\left(8.9 \mathrm{mg} \mathrm{l}^{-1}\right.$ at zero salinity) well exceeding that in seawater (7.9 $\mathrm{mg} \mathrm{l}^{-1}$ ) (Table 7). Taken together, the data support the working hypothesis that Sr concentrations are elevated in near-shore nursery sites (salinity 20 to 30 PSU) to levels higher than would be expected from mixing of seawater and average river water. This results from the significant augmentation of Sr levels in the fresh mixing-member by groundwater discharge.

\section{Magnesium and barium}

Mg and $\mathrm{Ba}$ in otoliths showed minor importance as discriminant variables (Tables 3 \& 5) for classification of fish to nursery area. $\mathrm{Mg}$ and $\mathrm{Ba}$ concentrations in groundwater were variable among nursery sites and generally showed the same negative trends with latitude as Sr, but the strength and uniformity of the relationships were lower. In the case of $\mathrm{Mg}$, although mean Mg concentrations in groundwater (PIS: $50 \mathrm{mg}$ $\mathrm{l}^{-1}$; TAB: $28 \mathrm{mg} \mathrm{l}^{-1}$; SGS: $5.6 \mathrm{mg} \mathrm{l}^{-1}$; SAB: $13 \mathrm{mg} \mathrm{l}^{-1}$; Rosenau et al. 1977, Hansard \& Silvanima 1999,) are higher than the world average river concentration (3.1 $\mathrm{mg} \mathrm{l}^{-1}$; Martin \& Whitfield 1981), the potential effect on $\mathrm{Mg}: \mathrm{Ca}$ ratios in polyhaline nursery waters, and therefore on otoliths (Table 2), is obscured by mixing with high $\mathrm{Mg}$ seawater (1.29 $\mathrm{g} \mathrm{l}^{-1}$; Martin \& Whitfield 1981, Drever 1988). With Ba, the otolith trend follows the groundwater trend. Measurable differences in otolith $\mathrm{Ba}$ :Ca ratios were observed among sites (mean $\left.\pm \mathrm{SD}, \mu \mathrm{mol} \mathrm{mol}{ }^{-1}\right)$ : PIS $=4.0 \pm 3.5, \mathrm{TAB}=$ $2.9 \pm 1.7, \mathrm{SGS}=2.1 \pm 0.8, \mathrm{SAB}: 1.7 \pm 0.6$. However, the relatively large variability in otolith Ba data (Table 2) reduced its importance as a discriminant variable.

\section{Carbon isotopes}

Carbon isotopes in otoliths, in contrast to oxygen isotopes, are not deposited in or near thermodynamic equilibrium with the ambient habitat. Factors in- 
Table 7. Mycteroperca microlepis. Sr:Ca ratios in otoliths and waters. $\mathrm{Sr}_{\mathrm{water}}$ Estimated: estimated from linear-mixing models for ground, river or Crescent Beach spring waters with seawater to 30 PSU. End-member data: groundwater from Hansard \& Silvanima (1999) and Rosenau et al. (1977), river from Martin \& Whitfield (1981), Crescent Beach from Swarzenski et al. (2001),

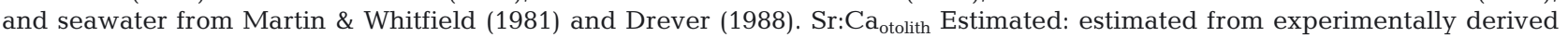
partition coefficients at $25^{\circ} \mathrm{C}$ (Bath et al. 2000) and estimated $\mathrm{Sr}: \mathrm{Ca}_{\text {water }}$

\begin{tabular}{|c|c|c|c|c|c|c|}
\hline \multirow[t]{2}{*}{ Mixing end-member } & \multicolumn{3}{|c|}{ End-member } & \multirow{2}{*}{$\begin{array}{c}\mathrm{Sr}: \mathrm{Ca}_{\text {water }} \\
\text { Estimated } \\
\left(\mathrm{mmol} \mathrm{mol}{ }^{-1}\right)\end{array}$} & \multirow{2}{*}{$\begin{array}{c}\mathrm{Sr}: \mathrm{Ca}_{\text {otolith }} \\
\text { Measured } \\
\left(\mathrm{mmol} \mathrm{mol}^{-1}\right)( \pm \mathrm{SD})\end{array}$} & \multirow{2}{*}{$\begin{array}{c}\mathrm{Sr}: \mathrm{Ca}_{\text {otoloth }} \\
\text { Estimated } \\
\left(\mathrm{mmol} \mathrm{mol}^{-1}\right)( \pm 95 \% \mathrm{CI})\end{array}$} \\
\hline & $\begin{array}{c}\text { Salinity } \\
\text { (PSU) }\end{array}$ & $\begin{array}{c}\mathrm{Sr}_{\text {water }} \\
\left(\mathrm{mg} \mathrm{l}^{-1}\right)\end{array}$ & $\begin{array}{r}\mathrm{Ca}_{\text {water }} \\
\left(\mathrm{mg} \mathrm{l}^{-1}\right)\end{array}$ & & & \\
\hline PIS groundwater ${ }^{a}$ & $0.9^{b}$ & 9.4 & 114 & 10.1 & $2.0 \pm 0.2$ & $2.1 \pm 0.4$ \\
\hline TAB groundwater ${ }^{\mathrm{a}}$ & $0.6^{\mathrm{b}}$ & 4.4 & 77 & 9.3 & $1.9 \pm 0.2$ & $1.9 \pm 0.4$ \\
\hline SGS groundwater ${ }^{\mathrm{a}}$ & $0.2^{\mathrm{b}}$ & 0.65 & 53 & 8.7 & $1.7 \pm 0.2$ & $1.8 \pm 0.3$ \\
\hline SAB groundwater ${ }^{\mathrm{a}}$ & $0.1^{\mathrm{b}}$ & 0.20 & 23 & 8.8 & $1.6 \pm 0.1$ & $1.8 \pm 0.3$ \\
\hline World average river & 0 & 0.060 & 13.3 & 8.8 & - & $1.8 \pm 0.3$ \\
\hline Crescent Beach submarine spring & 6.02 & 8.8 & 285 & 9.5 & - & $1.9 \pm 0.4$ \\
\hline Seawater & 35 & 7.9 & 412 & - & - & - \\
\hline
\end{tabular}

fluencing the $\delta^{13} \mathrm{C}$ of otoliths have recently been reviewed (Campana 1999), and include temperature, isotopic composition of water and diet, and metabolic rate of the fish. Metabolic rate is in turn influenced by life stage and temperature. Campana (1999) reports (data derived from Kalish 1991 and Thorrold et al. 1997) an average inverse temperature effect on $\delta^{13} \mathrm{C}$ of $0.2 \%$ o ${ }^{\circ} \mathrm{C}^{-1}$, which is in agreement with recent experimental results (Høie et al. 2003). In the present study, the observed differences in mean $\delta^{13} \mathrm{C}$ and temperature between the northern and southern sites each year (Tables $2 \& 6$ ) followed the expected trend, whereas the magnitude of $\delta^{13} \mathrm{C}$ differences were 3 to 10 times higher than expected from temperature effects alone. Clearly other factors affect $\delta^{13} \mathrm{C}$. The diet of juvenile gag in the size range of this study primarily consists of fish and decapods, averaging about $50 \%$ each (Mullaney \& Gale 1996, C. Koenig unpubl. data). Thus, a trophic level effect from diet is unlikely. A weak, positive relationship between $\delta^{13} \mathrm{C}$ and standard length with all data was detected by regression ( $\mathrm{n}=89, \mathrm{p} \leq 0.05, \mathrm{r}^{2}=0.21$ ), which suggests a possible reduction in metabolic rate with increasing size. However, a covariate effect of standard length on $\delta^{13} \mathrm{C}$ was not detected, and so if a metabolic rate effect does exist, it is small and unimportant in the classification of fish to nursery area. This suggests that the isotopic composition of the water and diet are dominant influences on observed $\delta^{13} \mathrm{C}$. Metabolic sources are expected to significantly contribute to otolith carbon (Kalish 1991, Schwarcz et al. 1998), which in the present case is expected to be from the diet. Dissolved inorganic carbon is the likely source of a large fraction of the remaining carbon (Campana 1999), but we are not aware of carbon isotope data for the study region to allow investigation of this contention.

\section{CONCLUSION}

We measured 12 chemical variables in gag otoliths from 4 nursery areas (sites) in 3 yr along the west coast of Florida with the goal of classifying fish to their nursery area based on their otolith composition. $\mathrm{Mn}, \mathrm{Sr}$ and $\delta^{13} \mathrm{C}$ emerged as important discriminant variables. Independent parametric statistical and neural network simulation approaches provided similar spatial and temporal patterns of success rates for classification. Success rates for classification to site using all data ( 4 sites and $3 \mathrm{yr}$ ) were 66 to $76 \%$, whereas rates increased to 80 to $100 \%$ for classification within a single year. This result demonstrates a significant and variable temporal effect over the spatial scale of site separation $(<200 \mathrm{~km})$ and the need to consider yearclass at these scales. When the spatial scale was increased to regional scale $(>300 \mathrm{~km})$ and data from all 3 yr were included, the success rates remained high at 92 to $94 \%$. This suggests that otolith composition is influenced by a broad regional pattern in the chemical composition of the habitat that is stable over at least several annual cycles (1993 to 1996). Analysis of specific classification errors supported the separation of the 4 sites into northern and southern groups. High success rates (94 to $95 \%$ ) for direct classification into these regional groups across all years sustains the idea of stable regional patterns in habitat composition that drive resultant otolith composition.

Existing environmental data provide explanations for the observed along-coast trends in otolith concentrations for $\mathrm{Mn}$ and $\mathrm{Sr}$, the 2 principal elements influencing classification success. Otolith Mn concentration displays a positive trend with increasing latitude consistent with a similar trend in total Mn concentration in coastal and estuarine sediments. Mobilization of sedi- 
ment $\mathrm{Mn}$ into the dissolved phase of overlying waters is recognized as a widespread phenomenon driven by the redox chemistry of surficial sediments and nearbottom waters. The negative trend in otolith $\mathrm{Sr}$ with increasing latitude correlates with a similar trend in coastal groundwater Sr. Groundwater discharge in the form of surface and submarine seeps and springs and leaching of aquifer solids by intruding seawater are recognized as important sources of water and dissolved materials for the west Florida coastal shelf, and thus for gag nursery sites. These correlations propose an explanation for the sources of dissolved $\mathrm{Mn}$ and $\mathrm{Sr}$ taken up into otoliths and the observed otolith concentration patterns among sites. They provide an interim basis for sampling design for the further characterization of gag nursery areas, and a working hypothesis to be tested. The ability to trace juvenile habitats by chemical markers in adult fish otoliths is an additional potentially useful tool for identifying important nursery areas pursuant to protection of their productivity and for the refinement of a recruitment index of fishery abundance based on juvenile abundance.

Acknowledgements. The National Marine Fisheries Service (NOAA Fisheries) supported this research. A number of people contributed in various ways, large and small, to this study, and deserve thanks. The authors particularly thank L. S. Chasar, D. R. Colby, J. Hare, C. W. Krouse, S. Narayan, and D. Vaughan for useful discussions and review during this research. Thanks are extended to G. Fisher, B. Leimburg and B. Sharack for their able technical assistance. The manuscript benefited from comments of 3 anonymous reviewers. The Florida Department of Environmental Protection helped to locate and supply data for the chemical composition of groundwater and sediment. Carbon and oxygen isotope data were supplied under contract by Mountain Mass Spectrometry (Evergreen, Colorado).

\section{LITERATURE CITED}

Bath GE, Thorrold SR, Jones CM, Campana SE, McLaren JW, Lam JWH (2000) Strontium and barium uptake in aragonitic otoliths of marine fish. Geochim Cosmochim Acta 64: 1705-1714

Buckel JA, Sharack BL, Zdanowicz VS (2004) Effect of diet on otolith composition in an estuarine piscivore. J Fish Biol (in press)

Cable JE, Burnett WC, Chanton JP, Weatherly GL (1996) Estimating groundwater discharge into the northeastern Gulf of Mexico using radon-222. Earth Planet Sci Lett 144: 591-604

Campana SE (1999) Chemistry and composition of fish otoliths: pathways, mechanisms and applications. Mar Ecol Prog Ser 188:263-297

Campana SE, Thorrold SR (2001) Otoliths, increments, and elements: keys to a comprehensive understanding of fish populations? Can J Fish Aquat Sci 58:30-38

Campana SE, Fowler AJ, Jones CM (1994) Otolith elemental fingerprinting for stock identification of Atlantic cod (Gadus morhua) using laser ablation ICPMS. Can J Fish
Aquat Sci 51:1942-1950

Campana SE, Gagne JA, McLaren JW (1995) Elemental fingerprinting of fish otoliths using ID-ICPMS. Mar Ecol Prog Ser 122:115-120

Coleman FC, Koenig CC, Collins LA (1996) Reproductive styles of shallow-water groupers (Pisces: Serranidae) in the eastern Gulf of Mexico and the consequences of fishing spawning aggregations. Environ Biol Fish 47:129-141

Daskalakis KD, O'Connor TP (1995) Distribution of chemical concentrations in US coastal and estuarine sediment. Mar Environ Res 40:381-398

de Lafontaine Y, Lambert T, Lilly GR, McKone WD, Miller RJ (1992) Juvenile stages: the missing link in fisheries research. Report of a workshop. Oct 1-3, 1991. Can Tech Rep Fish Aquat Sci Report no. 1890. Bedford Institute of Oceanography, Dartmouth, NS

Drever JI (1988) The geochemistry of natural waters. Prentice Hall, Upper Saddle River, NJ

Dufour V, Pierre C, Rancher J (1998) Stable isotopes in fish otoliths discriminate between lagoonal and oceanic residents of Taiaro Atoll (Tuamotu Archipelago, French Polynesia). Coral Reefs 17:23-28

Durako MJ, Phillips RC, Lewis RR III (eds) (1987) Proceedings of the symposium of subtropical-tropical seagrasses of the southeastern United States. Fla Mar Res Publ 42:1-209

Fanning KA, Breland JA, Byrne RH (1982) Radium-226 and radon-222 in the coastal waters of west Florida: high concentrations and atmospheric degassing. Science 215: $667-670$

Fanning KA, Torres L, Breland JA (1987) ${ }^{226} \mathrm{Ra}$ and ${ }^{222} \mathrm{Rn}$ along Florida's coasts. In: Proc Symp Natural Radiation and Technologically Enhanced Natural Radiation in Florida May 6-8, 1987, Daytona Beach, FL. Chapter of the Health Physics Society, Winter Haven, p 203-209

Fitzhugh GR, Lombardi-Carleson LA, Evou NM (2001) Gag (Mycteroperca microlepis) age structure from the eastern Gulf of Mexico: 1991-2000. National Marine Fisheries Service, Southeast Fisheries Science Center, Panama City Laboratory contribution series 01-02, Panama City, FL

Garson GD (1991) Interpreting neural-network connection weights. AI Expert 6:47-51

Geman SE, Bienenstock E, Doursat R (1992) Neural networks and the bias/variance dilemma. Neural Computation 4: $1-58$

Gillanders BM, Kingsford MJ (1996) Elements in otoliths may elucidate the contribution of estuarine recruitment to sustaining coastal reef populations of a temporate reef fish. Mar Ecol Prog Ser 141:13-20

Gillanders BM, Kingsford MJ (2000) Elemental fingerprints of otoliths of fish may distinguish estuarine 'nursery' habitats. Mar Ecol Prog Ser 201:273-286

Goh ATC (1995) Back-propagation neural networks for modeling complex systems. Artif Intelligence Eng 9:143-151

Hansard P, Silvanima J (1999) General water information system, Version 3 (GWIS3, CD-ROM). Florida Department of Environmental Protection, Tallahassee, FL

Hanson PJ, Zdanowicz VS (1999) Elemental composition of otoliths from Atlantic croaker along an estuarine pollution gradient. J Fish Biol 54:656-668

Hanson PJ, Evans DW, Colby DR, Zdanowicz VS (1993) Assessment of elemental contamination in estuarine and coastal environments based on geochemical and statistical modeling of sediments. Mar Environ Res 36:237-266

Haykin S (1999) Neural networks: a comprehensive foundation, 2nd edn. Prentice Hall, Upper Saddle River, NJ

Høie H, Folkvord A, Otterlei (2003) Effect of somatic and otolith growth rate on stable isotope composition of early 
juvenile cod (Gadus morhua L.) otoliths. J Exp Mar Biol Ecol 289:41-58

Ingram BL, Sloan D (1992) Strontium isotopic composition of estuarine sediments as paleosalinity-paleoclimate indicator. Science 255:68-72

Kalish JM (1991) ${ }^{13} \mathrm{C}$ and ${ }^{18} \mathrm{O}$ isotopic disequilibria in fish otoliths: metabolic and kinetic effects. Mar Ecol Prog Ser 75:191-203

Kimura R, Secor DH, Houde ED, Piccoli PM (2000) Up-estuary dispersal of young-of-the-year bay anchovy Anchoa mitchilli in the Chesapeake Bay: inferences from microprobe of strontium in otoliths. Mar Ecol Prog Ser 208: $217-227$

Koenig CC, Coleman FC (1998) Absolute abundance and survival of juvenile gag, Mycteroperca microlepis, in seagrass beds of the northeastern Gulf of Mexico. Trans Am Fish Soc 127:44-55

Koenig CC, Coleman FC, Collins LA, Sadovy Y, Colin PL (1996) Reproduction in gag (Mycteroperca microlepis) in the eastern Gulf of Mexico and the consequences of fishing spawning aggregations. In: Arrequin-Sanchez F, Munro JL, Balgos MC, Pauly D (eds) Biology, fisheries and culture of tropical groupers and snappers: proceedings of an EPOMEX/ICLARM International Workshop on Tropical Snappers and Groupers, University of Campeche, Campeche, Mexico, 26-29 Oct 1993. International Center for Living Aquatic Resources Management (ICLARM), Makati City, p 301-323

Limburg KE (1995) Otolith strontium traces environmental history of subyearling American shad Alosa sapidissima. Mar Ecol Prog Ser 119:25-35

Martin JM, Whitfield M (1981) The significance of river input of chemical elements to the ocean. In: Wong CS, Boyle E, Bruland KW, Burton JD, Goldberg ED (eds) Trace metals in sea water. Plenum Press, New York, p 265-296

Moore WS, Shaw TJ (1998) Chemical signals from submarine fluid advection onto the continental shelf. J Geophys Res 103:21543-21552

Mullaney MD Jr, Gale LD (1996) Ecomorphological relationships in ontogeny: anatomy and diet in gag, Mycteroperca microlepis (Pisces: Serranidae). Copeia 1:167-180

Palmer MR, Edmond JM (1989) The strontium isotope budget of the modern ocean. Earth Planet Sci Lett 92:11-26

Rosenau JC, Faulkner GL, Hendry CW Jr, Hull RW (1977) Springs of Florida. Geological Bulletin 31 (Revised). Bureau of Geology, Florida Department of Natural Resources, Tallahassee, FL

Rutkowski CM, Burnett WC, Iverson RL, Chanton JP (1999) The effect of groundwater seepage on nutrient delivery and seagrass distribution in the northeastern Gulf of Mexico. Estuaries 22:1033-1040

SAS Institute (1989a) SAS/STAT user's guide, Version 6, 4th edn, Vol. 1. SAS Institute, Cary, NC

SAS Institute (1989b) SAS/STAT user's guide, Version 6, 4th edn, Vol 2. SAS Institute, Cary, NC

SAS Institute (1990) SAS procedures guide, Version 6, 3rd edn. SAS Institute, Cary, NC

Schirripa MJ, Legault CM (1997) Status of the gag stocks of the Gulf of Mexico: Assessment 2.0. MIA-96/97-19.

Editorial responsibility: Otto Kinne (Editor),

Oldendorf/Luhe, Germany
National Marine Fisheries Service, Miami Laboratory, Miami, FL

Schwarcz HP, Gao Y, Campana S, Browne D, Knyf M, Brand U (1998) Stable carbon isotope variations in otoliths of Atlantic cod (Gadus morhua). Can J Fish Aquat Sci 55: 1798-1806

Seal TL, Calder FD, Sloane GM, Schropp S, Windom WL (1994) Florida coastal sediment contaminants atlas: a summary of coastal sediment quality surveys. Florida Department of Environmental Protection, Tallahassee, FL

Secor DH, Rooker JR, Zlokovitz E, Zdanowicz VS (2001) Identification of riverine, estuarine, and coastal contingents of Hudson River striped bass based upon otolith elemental fingerprints. Mar Ecol Prog Ser 211:245-253

Shaw TJ, Willard WS, Kloepfer J, Sochaski MA (1998) The flux of barium to the coastal waters of the Southeastern United States: the importance of submarine groundwater discharge. Geochim Cosmochim Acta 62:3047-3052

SNNS Group (1998) Stuttgart neural network simulator, user manual, Version 4.2, Wilhelm Schickard Institute for Computer Science, Tübingen

Swarzenski PW, Reich CD, Spechler RM, Kindinger JL, Moore WS (2001) Using multiple tracers to characterize the hydrogeology of the submarine spring off Crescent Beach, Florida. Chem Geol 179:187-202

Thamdrup B, Glud RN, Hansen JW (1994) Manganese oxidation and in situ manganese fluxes from a coastal sediment. Geochim Cosmochim Acta 58:2563-2570

Thorrold SR, Campana SE, Jones CM, Swart PK (1997) Factors determining delta ${ }^{13} \mathrm{C}$ and ${ }^{18} \mathrm{O}$ fractionation in aragonitic otoliths of marine fish. Geochim Cosmochim Acta 61: $2909-2919$

Thorrold SR, Jones CM, Campana SE, McLaren JW, Lam JWH (1998a) Trace element signatures in otoliths record natal river of juvenile American shad (Alosa sapidissima). Limnol Oceanogr 43:1826-1835

Thorrold SR, Jones CM, Swart PK, Targett TE (1998b) Accurate classification of juvenile weakfish Cynoscion regali to estuarine nursery areas based on chemical signatures in otoliths. Mar Ecol Prog Ser 173:253-265

Turner SC, Porch CE, Heinemann D, Scott GP, Ortiz M (2001) Status of gag in the Gulf of Mexico: Assessment 3.0. Sustainable Fisheries Division Contribution SFD 01/02-134. National Marine Fisheries Service, Miami Laboratory, Miami, FL

Vazquez J, Perry K, Kilpatrick K (1998) NOAA/NASA AVHRR oceans pathfinder sea surface temperature data set, user's reference manual, Version 4.0, California Institute of Technology, JPL Publication D-14070, Pasadena, CA

Warnken KW, Gill GA, Griffin LL, Santschi PH (2001) Sediment-water exchange of $\mathrm{Mn}, \mathrm{Fe}, \mathrm{Ni}$ and $\mathrm{Zn}$ in Galveston Bay, Texas. Mar Chem 73:215-231

Yoshinaga JA, Nakama A, Morita M, Edmonds JS (2000) Fish otolith reference material for quality assurance of chemical analyses. Mar Chem 69:91-97

Zieman JC, Zieman RT (1989) The ecology of the seagrass meadows of the west coast of Florida: a community profile. US Fish Wildl Serv Biol Rep 85(7.25) US Dept. of the Interior, Washington, DC

Submitted: July 10, 2002; Accepted: September 16, 2003

Proofs received from author(s): January 27, 2004 